\title{
Erratum to: Echo Calling Narcissus: What Exceeds the Gaze of Clinical Ethics Consultation?
}

\author{
Jeffrey P. Bishop · Joseph B. Fanning • Mark J. Bliton
}

Published online: 9 July 2010

(C) Springer Science+Business Media B.V. 2010

Erratum to: HEC Forum (2010) 22(1):73-84

DOI 10.1007/s10730-010-9123-8

Paula Chidwick's name was misspelled throughout "Echo Calling Narcissus: What Exceeds the Gaze of Clinical Ethics Consultation?" HEC Forum 22(1) (2010). The authors of the article and the editor of HEC Forum regret this error.

The online version of the original article can be found under doi:10.1007/s10730-010-9123-8.

\section{J. P. Bishop ( $\square)$}

Tenet Chair of Health Care Ethics, Albert Gnaegi Center for Health Care Ethics, Saint Louis University, Salus Center, Room 527, 3545 Lafayette Ave, St. Louis, MO 63104-1314, USA

e-mail: jeffrey.bishop@vanderbilt.edu

\section{J. B. Fanning · M. J. Bliton}

Center for Biomedical Ethics and Society, Vanderbilt University, 2525 West End Ave., 4th Floor, Suite 400, Nashville, TN 37203, USA

e-mail: joe.fanning@vanderbilt.edu

M. J. Bliton

e-mail: mark.bliton@vanderbilt.edu 